\title{
Лекарственные препараты, лекарственные растения и БАДы с антиоксидантной активностью
}

\author{
Яшин Я.И., Веденин А.Н., Яшин А.Я. \\ ООО «Интерлаб», Москва \\ Поступила в редакцию 16.12.2016 г.
}

Во введении описана роль окислительного стресса, который предшествует или сопутствует многим болезням. Отмечена важная роль антиоксидантной терапии. Приведены типы природных антиоксидантов. Отмечена особенная роль флавоноидов, обладающих высокой антиоксидантной активностью.

Приведен краткий обзор лекарственных препаратов - антиоксидантов, успешно применяемых в медицинской практике в РФ. Впервые амперометрическим методом определена антиоксидантная активность некоторых из этих лекарственных препаратов, а также поливитаминов и экстрактов известных лекарственных растений. Приведен обзор последних публикаций по результатам клинических и терапевтических испытаний наиболее сильных природных антиоксидантов, доступных в чистом виде: куркумина, кверцетина, астаксантина, дигидрокверцетина, эпигаллокатехин галлата, ресвератрола и др., применение которых для лечения сердечнососудистых, онкологических и др. тяжелых болезней, считается перспективным.

Ключевые слова. Лекарственные препараты, лекарственные растения, антиоксидантная активность, амперометрический метод.

\section{Medical products, medicinal plants and BUDs with antioxidant activity}

\author{
Yashin Ya.I., Vedenin A.N., Yashin A.Ya. \\ Company «Interlab», Moscow
}

In introduction the role of oxidative stress which proceeds is described or accompanies many illnesses. The important role of antioxidant therapy is noted. Types of natural antioxidants are resulted. The especial role of flavonoids which, except strong antioxidant activity, possess many other things improving actions is noted.

The short review of medicines - the antioxidants successfully applied in medical practice in the Russian Federation is resulted. For the first time antioxidant activity of some of these medicines by amperometric method, and also polyvitamins and extracts of known medicinal grasses is determined. The list of last publications on clinical and therapeutic tests of the strongest natural antioxidants, accessible in the pure state is resulted: curcumin, quercetin, astaxanthin, dihydroquercetin, epigallocatechin gallate, resveratrol, etc. Big hopes of treatment of dangerous illnesses (cardiovascular, oncologic, etc.) assign to application of these strong antioxidants.

Keywords. medical products, medicinal plants, antioxidant activity, amperometric method.

\section{Введение}

В последние годы проявляется большой интерес к окислительному стрессу, при котором нарушается окислительно - восстановительный баланс в организме человека. 
Окислительный стресс связан с повышенным содержанием в организме человека реакционных кислородных и азотных соединений, в т.ч. свободных радикалов. Научные исследования последнего десятилетия показывают, что окислительный стресс предшествует или сопутствует многим болезням - сердечнососудистым, онкологическим, сахарному диабету, нарушениям мозгового кровообращения, воспалительным, ревматоидным, нейродегенеративным (Паркинсона, Альцгеймера, шизофрении, аутизму). Подавляющее большинство теорий старения также основано на свободнорадикальном окислении.

Окислительный стресс у человека может быть достоверно установлен по наличию в биологических жидкостях специальных маркеров, появляющихся в результате воздействия на молекулы ДНК, белков, липидов и углеводов реакционных кислородных и азотных соединений, включая и свободные радикалы.

Общепринято считать, что лекарственные препараты - антиоксиданты и природные антиоксиданты могут защищать нас от вредного воздействия реакционных кислородных и азотных соединений (РКАС), включая и свободные радикалы при их избыточном содержании. РКАС и свободные радикалы выполняют в организме разнообразные биологические функции. Их превышение контролируется естественной системой антиоксидантной защиты человека. При некоторых неблагоприятных факторах (стрессы, облучения: радиационное, УФ, рентгеновское и др., загрязнения пищи и окружающей среды, воздействие некоторых лекарственных препаратов и лекарственных процедур, сильный перегрев или охлаждение, чрезмерные физические нагрузки и др.) система антиоксидантной защиты не справляется, и РКАС и свободные радикалы начинают повреждать жизненноважные молекулы ДНК, белков и липидов. Эти радикалы особенно активно взаимодействуют с мембранными липидами, содержащими ненасыщенные связи, что приводит к нарушению многих обменных процессов. Самые активные свободные радикалы разрывают связи в молекулах ДНК, тем самым повреждая генетический аппарат клеток, регулирующих их рост, что может привести к онкологическим заболеваниям. Липопротеиды низкой плотности после окисления свободными радикалами легко откладываются на стенках сосудов, приводя к ускоренному развитию атеросклероза и сердечнососудистым заболеваниям. В настоящее время показано, что сотням болезней предшествует окислительный стресс. Цель публикации - обобщение сведений об антиоксидантной активности лекарственных препаратов, лекарственных растений и БАДов, которые широко используются в клинической практике.

\section{Обсуждение результатов}

В случае диагностики окислительного стресса должна помочь антиоксидантная терапия - потребление лекарственных препаратов - антиоксидантов и/или пищевых продуктов с определенным содержанием природных антиоксидантов. Правильная и своевременная антиоксидантная терапия может предупредить развитие болезней на самой ранней стадии [1-9].

В последнее десятилетие появился новый класс лекарственных препаратов антиоксидантов, которые нашли разнообразное применение в клинической медицине [6-15]. Некоторые лекарственные препараты и БАДы из этой группы приведены в таблице 1 .

Кроме лекарственных препаратов, приведенных в таблице 1, можно указать еще на следующие: эмоксипин, аурол, дилудин, пробукол и многие другие. Некоторые из них, такие как лекарственные препараты для инъекций галавит и тамерит, имеют высокую антиоксидантную активность [6]. 
Таблица 1. Лекарственные препараты - антиоксиданты

\begin{tabular}{|c|c|c|}
\hline Название & Состав, действующие вещества & Назначение \\
\hline $\begin{array}{l}\text { Гипоксен (поли- } \\
\text { фен, олифен, ак- } \\
\text { товегин) }\end{array}$ & $\begin{array}{c}\text { Полидигидроокси- } \\
\text { фенилентио сульфат натрия }\end{array}$ & $\begin{array}{c}\text { Для повышения работоспособности } \\
\text { в экстремальных условиях (высоко- } \\
\text { горье, подводные работы); при ум- } \\
\text { ственном и физическом перенапря- } \\
\text { жении; терапии стабильной стено- } \\
\text { кардии, артериальной гипертензии, } \\
\text { хронической сердечной недоста- } \\
\text { точности } \\
\\
\text {. }\end{array}$ \\
\hline Мексидол & $\begin{array}{l}\text { Этилметилгидрокси- } \\
\text { пиридина сукцинат }\end{array}$ & $\begin{array}{c}\text { Для профилактики сердечно- } \\
\text { сосудистых заболеваний за счет } \\
\text { антиоксидантного и антигипоксант- } \\
\text { ного действия } \\
\end{array}$ \\
\hline Кудесан & Коэнзим Q10 & $\begin{array}{c}\text { Для профилактики сердечно- } \\
\text { сосудистых заболеваний }\end{array}$ \\
\hline Капотен & Каптоприл & $\begin{array}{c}\text { Для снижения артериального дав- } \\
\text { ления }\end{array}$ \\
\hline Нобен & Идебенон & $\begin{array}{c}\text { Для улучшения кровоснабжения и } \\
\text { оксигенации тканей мозга; как ан- } \\
\text { тиоксидант замедляет перекисное } \\
\text { окисление липидов, предохраняя } \\
\text { мембраны нейронов и митохондрий } \\
\text { от повреждений; обладает ноотроп- } \\
\text { ными свойствами } \\
\end{array}$ \\
\hline Дибикор & Таурин & Метаболическое средство, \\
\hline Капилар & Дигидрокверцетин & $\begin{array}{c}\text { Для улучшения кровоснабжения, } \\
\text { профилактики сердечно-сосудистых } \\
\text { заболеваний } \\
\end{array}$ \\
\hline Веторон & Бета-каротин, витамины Е и С & Для укрепления иммунитета \\
\hline Визио - баланс & $\begin{array}{c}\text { Экстракт календулы } \\
\text { (лютеин, зеаксантин); } \\
\text { порошок ягод черники; } \\
\text { экстракт кожуры винограда }\end{array}$ & $\begin{array}{c}\text { Для лечения катаракты, коррекции } \\
\text { различных дисфункций зрения }\end{array}$ \\
\hline Теагал & $\begin{array}{c}\text { Эпигаллокатехингаллат, } \\
\text { олигопроантоцианидины, } \\
\text { витамины Е, С, В6, В12, } \\
\text { фолиевая кислота, аргинин, } \\
\text { таурин, фениаланин }\end{array}$ & $\begin{array}{c}\text { Для нормализации артериального } \\
\text { давления, предотвращения развития } \\
\text { атеросклероза, тромбозов, снижения } \\
\text { риска сердечно-сосудистых заболе- } \\
\text { ваний, инфаркта миокарда, инсуль- } \\
\text { та, аритмий, снижения избыточного } \\
\text { веса } \\
\end{array}$ \\
\hline Хофитол & Экстракт листьев артишока & $\begin{array}{c}\text { Для снижения содержания холесте- } \\
\text { рина и мочевины в крови; Обладает } \\
\text { гепатопротекторным действием }\end{array}$ \\
\hline Tocovid & $\begin{array}{c}\text { Альфа, гамма, бета - } \\
\text { токотриенолы, альфа - } \\
\text { токоферол, фитостеролы, } \\
\text { сквален, каротиноиды } \\
\text { из природного пальмового } \\
\text { масла } \\
\end{array}$ & $\begin{array}{c}\text { Для предотвращения инсультов, } \\
\text { сердечно-сосудистых заболеваний, } \\
\text { онкологических заболеваний, защи- } \\
\text { ты печени }\end{array}$ \\
\hline Полиоксидоний & Азоксимера бромид & $\begin{array}{c}\text { Для профилактики и лечения ин- } \\
\text { фекционно - воспалительных забо- } \\
\text { леваний верхних дыхательных пу- } \\
\text { тей, внутреннего и среднего уха, } \\
\text { околоносных пазух }\end{array}$ \\
\hline
\end{tabular}


В последние годы разрабатываются гибридные антиоксиданты, сочетающие свойства как лекарственных препаратов, так и сильных антиоксидантов. Антиоксидантная активность определяется наличием в молекулах функциональных групп $\mathrm{OH}$ и $-\mathrm{SH}$, а лечебный эффект - другими функциональными группами, действующими независимо $[15,17]$.

Некоторые из гибридных антиоксидантов синтезированы в Институте биохимической физики РАН имени Н.М.Эммануэля. Весьма перспективны гибридные антиоксиданты на базе фуллеренов $\left(\mathrm{C}_{60}-\mathrm{Na}\right.$ - соль аминомасляной кислоты).

Академик В.П.Скулачев синтезировал гибридный антиоксидант на основе тетрафенилфосфата (супер-ион-антиоксидант Скулачева), который способен проникать в митохондрии клеток [12].

Самые сильные антиоксиданты - полифенолы: флавоноиды (восемь типов), фенольные кислоты (производные бензойной и коричной кислот), стильбены, производные кумарина, лигнаны, фенольные полимеры (проантоцианидины, конденсированные таннины). Флавоноиды по антиоксидантной активности в десятки раз превышают антиоксидантную активность таких распространенных антиоксидантов, как витамины Е, С, бета-каротин и другие каротиноиды.

Флавоноиды кроме сильной антиоксидантной активности обладают также разнообразной физиологической активностью: антисклеротической, антигипертонической, антиканцерогенной, противовоспалительной, антиаллергической и др. Полезные оздоровительные действия флавоноидов обобщены в превосходной книге Макаровой М.Н. и Макарова В.Г. [18]. Потребление флавонолов существенно снижает риск возникновения инсульта $[19,20]$. Каротиноид ликопин оказался весьма эффективным против рака простаты [21], а лигнан секоизоларициресинол эффективен против гормонозависимых онкологических заболеваний (рак молочной железы, рак яичников у женщин и рак простаты у мужчин). Лигнан секоизоларициресинол содержится в значительных количествах в зернах льна. Регулярное потребление зерен льна на 70\% снижает риск заболевания раком молочной железы [22, 23]. Антоцианидины, содержащиеся в клюкве, весьма эффективны против воспалительных процессов в мочевыводящих путях у человека [23, 24].

Далее будут кратко охарактеризованы наиболее известные лекарственные препараты - антиоксиданты.

Гипоксен (полидигидроксифенилентиосульфонат натрия) синтезирован в середине 70-х годов прошлого века в Институте высокомолекулярных соединений и успешно прошел многочисленные клинические испытания в десятках медицинских учреждений. С 1996 г. разрешен к медицинскому применению. Гипоксен относится к фармакотерапевтической группе лекарственных препаратов «Антигипоксанты и антиоксиданты» [2].

Гипоксен - сильнейший антиоксидант, молекула которого содержит двенадцать гидроксильных групп, присоединенных к бензольным кольцам (рис.1). Гипоксен обладает высокой биодоступностью, что отличает его от других антиоксидантов. За счет высокой антиоксидантной активности гипоксен блокирует свободнорадикальные реакции, повышает активность антиоксидантных ферментов.

Гипоксен рекомендуется для комплексной терапии стенокардии, бронхиальной астмы, пневмонии, а также для повышения работоспособности лиц, находящихся в экстремальных условиях, при умственном и физическом перенапряжении.

Мексидол (этилметилгидроксипиридина сукцинат) (рис. 1) обладает антиоксидантными характеристиками, способен тормозить свободнорадикальное окисление, может снизить окислительный стресс. Области его применения в медицине весьма широки. Это - неврология, терапия, хирургия, психиатрия, наркология. 
Употребление мексидола показано при острых нарушениях мозгового кровообращения, эпилепсии, нейродегенеративных заболеваниях нервной системы (болезни Альцгеймера, Паркинсона и др.), при астенических состояниях, острых и хронических алкогольных интоксикациях [8].

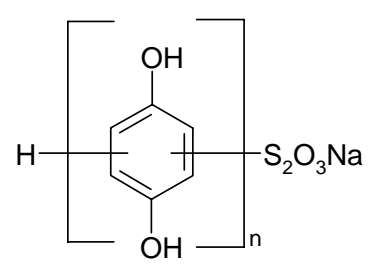

Гипоксен (полидигидрокси-<smiles>CCc1nc(C)ccc1O</smiles>

Мексидол фенилентиосульфонат натрия)

Рис. 1 Структурные формулы лекарственных препаратов -антиоксидантов.

Капотен в составе своей молекулы имеет тиольную группу (-S-H), придающую антиоксидантную активность.

Нобен (идебенон) синтезирован на основе убихинола (коэнзима $\mathrm{Q}_{10}$ ). Однако по сравнению с убихинолом молекула нобена в 5 раз меньше, она менее гидрофобна и обладает большей антиоксидантной активностью.

Нобен рекомендуется для приема при нарушениях мозгового кровообращения, памяти и внимания, при органических поражениях центральной нервной системы [11].

Теагал - натуральный (на основе эпигаллокатехина галлата зеленого чая) комплексный препарат для профилактики сердечнососудистых заболеваний (ишемической болезни сердца, гипертонической болезни, атеросклероза, аритмии). В препарате кроме основного компонента эпигаллокатехингаллата содержится экстракт виноградной косточки, витамины $\mathrm{E}, \mathrm{C}, \mathrm{B}_{6}, \mathrm{~B}_{12}$, фолиевая кислота, аргинин, таурин, фенилаланин. Основное действие теагала - антиоксидантное, противовоспалительное.

В России разработан и успешно применяется в клинической практике водорастворимый антиоксидант «Кудесан». «Кудесан» - комплексный антиоксидант, он содержит в 1 мл 30 мг коэнзима $\mathrm{Q}_{10}$ и 4,5 мг витамина $\mathrm{E}$ [14].

Действующим веществом препарата кудесан является коэнзим $\mathrm{Q}_{10}$ (убихинол, кофермент $\left.\mathrm{Q}_{10}\right)$. Коэнзим $\mathrm{Q}_{10}$ весьма важный и уникальный антиоксидант. Большинство антиоксидантов, в частности, витамины $\mathrm{E}, \mathrm{A}, \beta$-каротин, необратимо окисляются при взаимодействии со свободными радикалами. В отличие от них активная форма молекулы коэнзима $\mathrm{Q}_{10}$ регенерируется ферментной системой, и его молекулы используются многократно в нейтрализации свободных радикалов. Убихинол (антиоксидант) окисляется и переходит в убихинон. Под действием ферментов идет и обратный процесс. Кроме того, коэнзим $\mathrm{Q}_{10}$ может восстанавливать и активность витамина Е.

Коэнзим $\mathrm{Q}_{10}$ (убихинол) - один из важных природных антиоксидантов в организме человека. Кроме того, он принимает активное участие в жизнедеятельности многих органов человека [5], в частности, он обеспечивает функции клеточного дыхания. Антиокислительный эффект коэнзима $\mathrm{Q}_{10}$ доказан [5], он проявляется в защите клеток и тканей от повреждающего воздействия свободных радикалов.

За исследование функции коэнзима Q 10 П.Митчел в 1978 г. получил Нобелевскую премию.

Коэнзим $\mathrm{Q}_{10}$ синтезируется в организме человека в печени из аминокислоты тирозина в результате сложного биохимического процесса с участием ряда витаминов. Часть его мы получаем с пищей. Его относят к витаминоподобным вещест- 
вам [10].

Содержание коэнзима $\mathrm{Q}_{10}$ в пищевых продуктах ниже уровня, необходимого для нормального функционирования организма человека. Считается, что с пищей можно получить 5-10 мг коэнзима $\mathrm{Q}_{10}$, а суточная потребность в нем колеблется в пределах 50-150 мг [10].

$\mathrm{C}$ возрастом биосинтез коэнзима $\mathrm{Q}_{10}$ в организме человека постепенно снижается. Уменьшенная концентрация коэнзима $\mathrm{Q}_{10}$ в плазме обнаружена в ряде патологических состояний (диабет, онкологические заболевания, сердечно-сосудистые заболевания). Уменьшает концентрацию коэнзима $\mathrm{Q}_{10}$ в плазме прием некоторых лекарственных препаратов, его значительное снижение в организме смертельно опасно. Количественное определение коэнзима $\mathrm{Q}_{10}$ в плазме проводят методом хроматографии с электрохимическим детектором [16].

Ранее нами оценено содержание антиоксидантов в витаминах и витаминных комплексах [5], во многих гомеопатических препаратах при разных степенях разбавления амперометрическим методом на приборе «Близар». Представляют интерес данные о содержании антиоксидантов в лекарственных препаратах и БАДах, характеризирующие их антиоксидантную активность. В таблице 2 приведены данные о суммарном содержании антиоксидантов в некоторых лекарственных препаратах и БАДах. Суммарное содержание антиоксидантов пропорционально антиоксидантной активности этих препаратов, поэтому эти данные можно использовать при антиоксидантной терапии. Биологически активные добавки к пище (БАД) на основе натуральных продуктов полезны при дефиците в рационе питания человека антиоксидантов, витаминов и микроэлементов. Антиоксиданты признаются в настоящее время неотъемлемой частью здорового и полноценного питания [25]. Продукты с большим содержанием антиоксидантов включаются в функциональное питание. 90\% населения в Японии употребляют БАДы, 80\% в США, в нашей стране БАДы употребляют $15-20 \%$ населения, в основном люди пожилого возраста.

Таблица 2. Суммарное содержание антиоксидантов (ССА) в лекарственных препаратах и БАДах (стандарт - кверцетин)

\begin{tabular}{|c|c|c|}
\hline Наименование & Состав или действующее вещество & $\begin{array}{l}\mathrm{CCA}, \\
\mathrm{M \Gamma} / \Gamma\end{array}$ \\
\hline 1 & 2 & 3 \\
\hline Teavigo (БАД) & $\begin{array}{c}\text { Экстракт зеленого чая без кофеина (основной компонент - } \\
\text { эпигаллокатехин галлат) }\end{array}$ & 677.0 \\
\hline $\begin{array}{l}\text { Экстракт виноград- } \\
\text { ной косточки (БАД) }\end{array}$ & Биофлавоноиды, транс-ресвератрол & 263.0 \\
\hline $\begin{array}{c}\text { Сантерелла Жень- } \\
\text { шень (БАД) }\end{array}$ & Зеленый чай + женьшень & 216.0 \\
\hline Эпигаллат (БАД) & $\begin{array}{c}\text { Одна капсула содержит } 45 \text { мг чистого эпигаллокатехин гал- } \\
\text { лата из зеленого чая } \\
\end{array}$ & 184.0 \\
\hline $\begin{array}{l}\text { Selenium Forte } \\
\text { (БАД) }\end{array}$ & $\begin{array}{c}\text { Состав: селен, витамины С, Е, бета-каротин, цинк и ПНЖК } \\
\text { Омега-3 }\end{array}$ & 121.9 \\
\hline $\begin{array}{c}\text { Атероклефит (ле- } \\
\text { карственный препа- } \\
\text { рат) }\end{array}$ & Экстракт биофлавоноидов красного клевера & 103.6 \\
\hline Пикнолар (БАД) & Дигидрокверцетин & 103.4 \\
\hline $\begin{array}{c}\text { Дигидрокверцетин } \\
\text { П (БАД) } \\
\end{array}$ & Дигидрокверцетин & 101.7 \\
\hline Антиокс (БАД) & $\begin{array}{c}\text { Экстракт виноградной косточки, витамин С, Е, Гингко- } \\
\text { Билоба, бета-каротин, селен }\end{array}$ & 99.3 \\
\hline
\end{tabular}

Я 


\begin{tabular}{|c|c|c|}
\hline 1 & 2 & 3 \\
\hline $\begin{array}{c}\text { Софора+витамины } \\
\text { для сосудов (БАД) }\end{array}$ & $\begin{array}{c}\text { Витамины С, Е, В6, В12, ниацин, фолиевая кислота, селен, } \\
\text { магний, цинк, медь, флавоноиды софоры японской, Гингко- }\end{array}$ & 96.5 \\
\hline $\begin{array}{c}\text { Гипоксен (лекарст- } \\
\text { венный препарат) }\end{array}$ & Полидигидрооксифенилентио сульфат натрия & 85.4 \\
\hline $\begin{array}{c}\text { Гинкго Билоба } \\
\text { Форте (БАД) }\end{array}$ & $\begin{array}{c}\text { Гинкго-Билоба, зеленый чай, пыльца цветочная, лук суше- } \\
\text { ный }\end{array}$ & 79.0 \\
\hline $\begin{array}{c}\text { Экстракт виноград- } \\
\text { ной кожицы (БАД) }\end{array}$ & Проантоцианидины, транс-ресвератрол & 78.8 \\
\hline $\begin{array}{c}\text { Черника Форте с } \\
\text { витаминами и цин- } \\
\text { ком (БАД) }\end{array}$ & $\begin{array}{c}\text { Рутин, витамины группы В, витамин С, антоцианины черни- } \\
\text { ки }\end{array}$ & 59.7 \\
\hline Капилар (БАД) & Дигидрокверцетин & 14.9 \\
\hline
\end{tabular}

В таблице 3 приведены сведения по суммарному содержанию антиоксидантов (CСA) в лекарственных препаратах и БАДах, содержащих витамины.

Таблица 3. Суммарное содержание антиоксидантов (ССА) в лекарственных препаратах и БАДах, содержащих витамины (стандарт - кверцетин)

\begin{tabular}{|c|c|c|}
\hline № & Наименование & $\begin{array}{c}\text { ССA } \\
\text { мг/Г }\end{array}$ \\
\hline 1 & Поливитамин Perfectil & 206.5 \\
\hline 2 & Аскорбиновая кислота (драже, 50 мг) & 158.0 \\
\hline 3 & Алфавит & 125.0 \\
\hline 4 & Берокка Плюс & 102.3 \\
\hline 5 & Теравит Анти-стресс & 84.0 \\
\hline 6 & Витрум & 41.0 \\
\hline 7 & Поливит Слим с экстрактом зеленого чая & 41.0 \\
\hline 8 & Поливит 34 & 33.0 \\
\hline 9 & Поливит & 13.0 \\
\hline
\end{tabular}

Нами измерены значения антиоксидантной активности сухих экстрактов наиболее известных лекарственных растений. Активность уменьшается в следующем порядке: кора крушины $>$ кора дуба $>$ крапива $>$ лапчатка $>$ кора ивы $>$ шиповник $>$ пустырник $>$ подорожник $>$ чага $>$ солодка $>$ боярышник $>$ эхинацея $>$ элеутерококк $>$ зверобой $>$ календула $>$ расторопша $>$ корни алтея $>$ термопсис.

Суммарное содержание антиоксидантов в лекарственных растениях, выпускаемых ООО «Алтай-Фарм» приведены в таблице 4. Следует отметить высокое значение ССА корня кровохлебки и шлемника байкальского.

Таблица 4. Суммарное содержание антиоксидантов в лекарственных растениях, выпускаемых ООО «Алтай-Фарм», г. Барнаул (стандарт - кверцетин)

\begin{tabular}{|c|c|c|}
\hline № п/п & Название лекарственного растения & ССА, мг/Г \\
\hline 1 & 2 & 3 \\
\hline 1 & Кровохлёбка корень & 68.9 \\
\hline 2 & Шлемник байкальский & 60.2 \\
\hline 3 & Мать-и- мачеха & 18.9 \\
\hline 4 & Осина, кора & 18.6 \\
\hline 5 & Зверобой & 17.5 \\
\hline 6 & Солодка, корень & 14.2 \\
\hline 7 & Календула, цветки & 13.1 \\
\hline
\end{tabular}




\begin{tabular}{|c|c|c|}
\hline 1 & 2 & 3 \\
\hline 8 & Валериана & 8.6 \\
\hline 9 & Шалфей, лист & 7.3 \\
\hline 10 & Сосна, почки & 4.1 \\
\hline 11 & Одуванчик, корень & 3.2 \\
\hline
\end{tabular}

В последние годы стали доступны в чистом виде сильные природные антиоксиданты: кверцетин, дигидрокверцетин, ресвератрол, куркумин, астаксантин, эпигаллокатехин галлат и др. Они успешно проходят предклинические, клинические исследования при разных заболеваниях [26-39].

Кверцетин - один из самых сильных антиоксидантов среди флавоноидов, он в 2 раза сильнее дигидрокверцетина и рутина по антиоксидантной активности. Рутин это кверцетин с сахарным заместителем в положении 3. Широко используется в лечебных мазях. Кверцетин содержится во многих ягодах и фруктах, больше всего его в луке и яблоках. Дигидрокверцетин содержится в коре сибирской лиственницы, в РФ десятки фирм выделяют его в чистом виде с чистотой до 99\%. Куркумин содержится в куркуме в виде трех типов, куркумина 1 содержится более $70 \%$. Астаксантин - самый сильный антиоксидант из каротиноидов, он находится в морских водорослях, в красной рыбе и красной икре. В рыбе кижуч астаксантина в 8 раз больше, чем в лососе. Эпигаллокатехин галлат содержится в зеленом чае, около $70 \%$ от суммарного содержания всех катехинов, его выделяют в чистом виде в Швейцарии и уже используют в некоторых лекарственных препаратах. (Табл.1). Транс - ресвератрол содержится в некоторых лекарственных растениях и красном вине.

В последние годы сильно возрос интерес к измерениям антиоксидантной активности лекарственных растений и определению в них действующих начал методами хромато-масс-спектрометрии, в том числе на жидкостном хроматографе «МаэстроВЭЖХ». В работах [40 - 49] определена антиоксидантная активность лекарственных растений Китая [40, 46, 49], Индии [48], Хорватии [42], Польши [43], Болгарии [45], Ливии [47].

\section{Заключение}

Лекарственные препараты - антиоксиданты как синтетические, так и природные уже нашли широкое применение в клинической практике. Наиболее перспективно применение сильных природных антиоксидантов, выделенных в чистом виде из пищевых и растительных продуктов, сведения о некоторых из них приведены в обзоре. Большие надежды связывают с лекарственными растениями, интерес к которым сильно возрос в последнее время. Этот интерес обусловлен в первую очередь их высокой антиоксидантной активностью. Особенно велико количество исследований растительных препаратов традиционной китайской медицины (более 1000 наименований).

\section{Список литературы}

1. Nemzer B.V., Yashin Ya.I., Yashin A.Ya. // Current Gene Therapy 2008 Vol.8. pp.256-263. American Journal of Biomedical Sciences .2013. ～4. Firuzi O.; Miri R.; Tavakkoli M.; Saso L. // 5(2). pp. 80-108.

2. Iannitti T.; Palmieri B. // Eur Rev Med 3871 - 3888.

Pharmacol Sci. 2009 Vol. 13. No 4. pp.245- 5. Birben E.; Sahiner U.M.; Sackesen C.; Er278. zurum S. et al. // World Allergy Organ. J. 2012.

3. Ramos-Marquez, M.E.; Siller-Lopez, F.// Vol. 5. pp. 9-19. 
6. Яшин Я.И., Рыжнев В.Ю., Яшин А.Я., Черноусова Н.И. Природные антиоксиданты. Содержание в пищевых продуктах и их влияние на здоровье и старение человека. ТрансЛит. М. 2009. С. 212.

7. Коняхин А.Ю. Гипоксен в комплексной терапии стенокардии напряжения II-III ФК. Методические рекомендации. М., 2006, С. 2025.

8. Воронина Т.А. Отечественный препарат нового поколения «Мексидол». Основные эффекты, механизмы действия, применение. М. 2005. $22 \mathrm{c}$.

9. Дамулин И.В., Антоненко Л.М., Ласков В.Б., Шутеева Т.В. и др. Неврологический журнал. 2009. Т. 14. С. 1-8.

10. Кравцова Л.А., Березницкая В.В., Школьникова М.А. // Российский вестник перинатологии и педиатрии. 2007. № 6. С. 51-58.

11. Дамулин И.В. // Журнал неврологии и психиатрии. 2006 Т. 11. С. 66-71.

12. Скулачев В., Скулачев М., Фенюк Б. Жизнь без старости. ЭКСМО. М. 2013. 256 с.

13. Зайцев В.Г., Островский О.В., Закревский В.И. // Эксперим. клин. фармакол. 2003. C. 66-70.

14. Басинский С.Н., Басинский А.С., Рогачев И.Н. // Ученые записки Орловского Госуниверcumema. 2008. № 1. С.65-68.

15. Антиоксидантные свойства препарата «Кудесан». Применение в кардиологии. Ч.3. М., ИД «Медпрактика»- М. 2007. 56 с.

16. Е.Б.Бурлакова. Гибридные антиоксиданты. В сборнике «Биоантиоксиданты». РАН. M. 2006 C. 3-15.

17. Mosca F., Fattorini D., Fattorini D., Bonparde S., Littaru G.P., Anal Biochem., 2002, Vol. 305, p. 45.

18. Макарова М.Н., Макаров В.Г. Молекулярная биология флавоноидов. Руководство для врачей. СПб. 2010. 428 с.

19. Hollman P.C, Geelen A, Kromhout D. // $J$ Nutr. 2010. Vol. 140. pp. 600-604.

20. Shirley, R.; Ord, E.N.J.; Work, L.M. // Antioxidants. 2014. Vol. 3. pp.472-501.

21. Chen, J.; Song, Y.; Zhang, L. // Journal of Nutritional Science and Vitaminology, 2013. Vol. 59. pp. 213-223.

22. Мартинчик А.Н., Зубцов В.В. // Вопр. nuтания. 2012. № 6. С. 61-66.

23. Мартинчик А.Н., Батурина А.К., Зубцов В.В., Молофеев В.Ю. // Вопр. питания. 2012. T. 81. № 3. C. 4-10.

24. Blumberg, J.B.; Camesano, T.A.; Cassidy, A.; Kris-Etherton, P. et al. // An International
Review Journal 2013. Vol.4. pp. 618-632.

25. А.Я.Яшин, А.Н.Веденин, Я.И.Яшин Природные антиоксиданты - неотъемлемая часть здорового и полноценного питания и защита человека от опасных болезней. Обзор. В сборнике «Питание и обмен веществ». 4-й вып. Научный редактор - член-корр. А.Г. Мойсеёнок. Минск. 2016. С.378-394.

26. Patel D., Shukla S., Gupta S. // Int. J. Oncol. 2007. Vol. 30. No 1. pp. 239-245.

27. Hung H. // Forum Nutr. 2007. Vol. 60. pp.146-157.

28. Lin Y., Shi R., Wang X., Shen M. // Curr. Cancer Drug Targets. 2008. Vol. 8. No 7. pp. 634- 646

29. Epstein J., Sanderson I.R., MacDonald T.T. // Br. J. Nutr. 2010. Vol.103. No 11. pp. 15451557.

30. Goel A., Kunnumakkara A.B., Aggarwae B.B. // Biochem. Pharmacol. 2008. Vol. 75. No 4. pp. 787- 809 .

31. Hatcher H., Planalp R., Cho J., Torti F.M., Torti S.V. // Cell. Mol. Life Sci. 2008. Vol. 65. No 11. pp.1631-1652.

32. Rajasekaran S.A. // World J. Gastrointest. Pathophysiol. 2011. Vol.2. No 1. pp.1-14.

33. Yamashita E. // Func. Foods Health Dis. 2013. Vol. 3. pp. 254-258.

34. Hu T. He X.-W., Jiang J.-G., Xu X.-L. // J. Agric. Food Chem. 2014. Vol. 62. pp.1449-1453.

35. Zarebczan B., Pinchot S.N., Kunnimalacyaan M., Chen H // Am. J. Surg. 2011. pp. 329-332.

36. Legeay S., Rodier M., Fillion L., Faure S., Clere N. // Nutrients. 2015. Vol. 7. No 7. pp.51775216.

37. Haman F. // Foods and Nutrtic. Sci. 2014. Vol. 5. No 22. pp.2257-2264.

38. Miles S.L., McFarland M., Niles R.M. // Nutrition Review 2014. Vol. 11. pp. 720-734.

39. Fassatt R.G., Combles J.S. // Mol. Drugs 2011. Vol. 3. pp. 447-463.

40. Luo Y., Cai Q., Sun M., Corke H. // Life Science. 2004. Vol. 74. pp. 2157-2184.

41. Li S., Li S.K., Gan R.Y., Song F.L., Kuang L., Li H.B. // Ind. Crop. Prod. 2013. Vol. 51. pp. 289-298.

42. Katalinic V., Milos M., Jukic M. // Food chemistry 2008. Vol. 94. pp. 550-557.

43. Wojdylo A., Oszmianski J., Czemerys R. // Food Chemistry 2006. Vol. 97. pp. 654-660.

44. Djeridane A., Yosfi M. // Food chemistry 2006. Vol. 97. pp. 654-660.

45. Ivanova D., Gerova D., Charvankov T., Yankov T. // J. Ethoropharmacology 2005. Vol. 95. pp. 145- 160. 
46. Wong C.C., Li H.-B., Cheng K.-H., Chen F. M. // Food Chemistry 2007. Vol. 102. pp. 938// Food chemistry 2006. Vol.97. pp. 705-707. 953.

47. Hebail F. // Natural Science 2012. Vol. 4. pp. 49. Liu H.; Qiu N.; Ding H.; Yao R. // Food 324- 335 .

Research International. 2008. Vol. 41. pp.363-

48. Surveswaran S.; Cai Y.-Z.; Corke H.; Sun 370.

Яшин Яков Иванович - проф., д.Х.н., руководитель отдела исследований и разработок компании «Интерлаб», Москва

Веденин Александр Николаевич - президент компании «Интерлаб», Москва

Яшин Александр Яковлевич - к.х.н., зам. руководителя отдела исследований и разработок, Москва
Yashin Yakov I. - Doctor of Science (Chemistry), Professor, Head of the R\&D Department company "Interlab", Moscow

Vedenin Alexander N. - President of company "Interlab", Moscow

Yashin Alexander Ya. - $\mathrm{PhD}$ in Chemistry, Deputy head of the R\&D Department company "Interlab", Moscow 